\title{
Effect of fertilization, tiller cutting and environment on plant growth and yield of European blueberry (Vaccinium myrtillus L.) in Norwegian forest fields
}

\author{
Rolf Nestby ${ }^{\mathrm{a}, *}$, Inger Martinussen ${ }^{\mathrm{a}}$, Tore Krogstad ${ }^{\mathrm{b}}$ and Eivind Uleberg ${ }^{\mathrm{a}}$ \\ ${ }^{\mathrm{a}}$ Bioforsk - Norwegian Institute for Agricultural and Environmental Research, Ås, Norway \\ ${ }^{\mathrm{b}}$ University of Life Sciences, Institute of Environmental Sciences, Ås, Norway
}

Received 26 September 2013; accepted 2 December 2013

\begin{abstract}
.
BACKGROUND: European blueberry (E. blueberry; Vaccinium myrtillus L.) is a natural resource demanded by the processing industry with potential of domestication. Therefore an investigation of the possibilities of partial cultivation of native stands was started.

OBJECTIVE: To increase knowledge of how E. blueberry react to soil types, climate, mineral nutrition, organic amendments and cutting of tillers.

METHODE: Five forest fields with E.blueberry stands in Norway were examined. Besides natural development influenced by soil parameters and climate, effect of fertilization and plant pruning were examined in the municipalities of Bardu in Troms county $\left(68^{\circ} \mathrm{N}\right)$ and of Snåsa and Lierne in Nord-Trøndelag county $\left(64^{\circ} \mathrm{N}\right)$. Experiments were executed in randomized block designs in forest fields of native E. blueberry stands.

RESULTS: The fields that performed best had O-layers close to $7 \mathrm{~cm}$ or thicker. The $\mathrm{C} / \mathrm{N}$ ratios indicate that $\mathrm{N}$ was not easily available in any field, and addition of mineral fertilizer containing nitrogen and phosphor show that especially $\mathrm{N}$ increased elongation of long shoots and more nodes were developed. However, the effect on number of short shoots per long shoot initiated a growth gain only the last of two years. The positive growth effect of fertilizer was not followed by higher yields throughout the years, and strongest fertilization level (N60P40) reduced yield in average of four years. Adding composted wood chips or wood chips alone increased tiller growth in the birch-field in Bardu both years, but only the first year in the pine-field; this was not reflected in higher yield. Cutting of shoots to the ground reduced yield and full yield potential was not recovered before the third year after cutting.

CONCLUSION: The results suggest that by improving growth conditions, especially by securing a thick natural O-layer and adjusting soil macro nutrient composition, growth conditions could be improved; and that fruit yield were down the two first years after pruning.
\end{abstract}

Keywords: Bilberry, cultivation, native stand, soil type, climate, pruning

\section{Introduction}

The European blueberry (E. blueberry) (Vaccinium myrtillus L.), in English language often called bilberry, is a circumboreal calcifuge plant [7] related to the North American lowbush blueberry (Vaccinium angustifolium Ait.). In the Nordic countries the annual production of wild berries is estimated to be about 1 billion tons and a large part of

*Corresponding author: Rolf Nestby, Bioforsk - Norwegian Institute for Agricultural and Environmental Research, $1430 \AA ̊$ A , Norway. Tel.: +47 95988530; Fax: +47 74822008; E-mail: rolf.nestby@ bioforsk.no. 
this is blueberries [38]. In Norway the industrial exploitation of E. blueberry is minimal, the fruit, however, is strongly preferred by the Norwegian processing industry compared to lowbush blueberry. Industrial demand is mainly covered by imports from other European states like Sweden, Finland and states in Eastern Europe [38]. However, the practise of cultivating native stands of lowbush blueberry demonstrates a model that could be adapted to native E. blueberry stands [33].

E. blueberry ground vegetation is the most widespread vegetation type in Norwegian coniferous forests [7, 9] and is closely connected to podzol soil type. The plant has a shallow and weak root system mostly found in the O-horizon (organic top level) of podzolic soils [25]. The humus therefore appears to be of great importance to the blueberry vegetation [51]. The low $\mathrm{pH}$ of the natural growth medium suggests low plant availability for nutrients in general. However, deficiency symptoms of nitrogen $(\mathrm{N})$ and phosphorous $(\mathrm{P})$ have not been reported for blueberries of natural vegetation, even if they are high yielding. This is mainly due to the symbiosis with ericoid mycorrhiza, which provides access to $\mathrm{N}$ and $\mathrm{P}$ sources that would not be available to plant roots alone [31, 42].

Yields vary greatly from year to year in fields of native E. blueberry [31, 42]. The highest productivity and vitality of E. blueberry has been found in 40 to 80 and 200 years old pine forests, respectively in Poland and in Kola Russia $[20,27]$. A model has been made to determine yields of E. blueberry based on characteristics of the location and tree stand in Finland [17, 18]. This indicates challenges in establishing cultivated native stands of E. blueberry and to increase growth soon after clear cutting, as well as achieving yields somewhat near a quarter of the potential of cultivated lowbush blueberry (Vaccinium angustifolium Ait.).

The effect of single and multiple fertilizers have frequently been examined in lowbush blueberry, and it is shown that both foliar and soil application of fertilizers may be beneficial alone or in combination. Positive effects are obtained by fertilization with N, P, Ca, B and Zn. It seems as if diamoniumphosphate is an excellent source of $\mathrm{N}$ and $\mathrm{P}$, and that application of potassium (K) may have a negative effect $[40,47]$. On cultivated native stands of lowbush blueberry soil $\mathrm{pH}$ has to be decreased and normally $\mathrm{S}$ and acid-forming fertilizers are applied [1, 49]. Adding organic material as mulch is also frequently used, and may improve yield [26].

Nitrogen remobilisation and the growth response to $\mathrm{N}$ supply are closely linked to the pattern of bud activation [13]. In areas with high $\mathrm{N}$ deposition, E. blueberry is less frequent, less abundant and more susceptible to the leaf pathogen Valdensia heterodoxa than in areas with lower levels of $\mathrm{N}$ deposition [50].

A lowbush field takes approximately 10 years from clear cut to a fully established field [23]. Clear cutting of E. blueberry stands in Finland and Sweden indicate that it could take longer since the ground covering were reduced $[2,37]$, while a Norwegian study reported improved plant growth when clear cuttings were smaller than in Finland and Sweden [34].

It is important to choose the right fields for partial cultivation of native E. blueberry stands in order to avoid frost during flowering, extreme wind conditions and drought $[15,35,39]$. The mild winters of the last decades have initiated lethal plant injuries in E. blueberry in Sweden, especially during misty and wet weather [36, 52, 53], which show the importance to select fields with stable snow cover during winter and/or fields that are avoiding low temperatures by other means, like location. Drought stress in $V$. angustifolium leads to a partition of resources into vegetative growth and into reproductive growth when moisture levels are sufficient $[11,12,46]$. Similar conditions are probably significant also for the E. blueberry, although it was found that the level of $\mathrm{N}$ turnover in the soil O-horizons in a Norwegian spruce forest was not affected by drying or wetting of the layers [3].

Here, investigations were undertaken in different Norwegian regions with varying climate and soil conditions in order to increase the knowledge of how E. blueberry react to mineral nutrition, organic amendments and cutting of tillers.

\section{Material and methods}

\subsection{Field descriptions}

Five forest fields were established in cooperation with landowners in north- and mid- Norway (Table 1). Two fields (F1, F2) were established in 2008 at Sørdalen in Bardu municipality, county of Troms in northern Norway at different field types. Both fields are on horizontal plains of silty sand soil, and the geology in the area is mica schist 
Table 1

Forest field location, location ID, coordinates, meters above sea level (Mas), experiments with block and plot size and no of replicates (R), and forest type in Norway

\begin{tabular}{|c|c|c|c|c|c|c|c|c|}
\hline Location & ID & Coordinates & Mas & Experiment & Block size $\left(\mathrm{m}^{2}\right)$ & Plot size $\left(\mathrm{m}^{2}\right)$ & $\mathrm{R}$ & Forest type \\
\hline \multirow[t]{2}{*}{ Sørdalen } & $\mathrm{F} 1$ & $\mathrm{~N}^{\circ} 8^{\circ} 43.55^{\prime} \mathrm{E} 18^{\circ} 32.68^{\prime}$ & 85 & Compost and wood chips & $15 \times 15$ & $2 \times 2$ & 3 & B. pubescens \\
\hline & $\mathrm{F} 2$ & $\mathrm{~N}^{\circ} 8^{\circ} 44.48^{\prime} \mathrm{E} 18^{\circ} 32.33^{\prime}$ & 85 & Compost and wood chips & $15 \times 15$ & $2 \times 2$ & 3 & Pinus silvestris \\
\hline Snåsa & F3 & $64^{\circ} 18.011^{\prime} 12^{\circ} 28.42^{\prime}$ & 297 & $\begin{array}{l}\text { Mineral fertilization, } \\
\text { cutting, site }\end{array}$ & $15 \times 15$ & $3.75 \times 15$ & 5 & $\begin{array}{l}\text { Picea abies, } \\
\text { B. Pubescens }\end{array}$ \\
\hline \multirow[t]{2}{*}{ Lierne } & $\mathrm{F} 4$ & $64^{\circ} 29.99^{\prime} 013^{\circ} 29.99^{\prime}$ & 427 & Mineral fertilization & $15 \times 15$ & $3.75 \times 15$ & 5 & Picea abies \\
\hline & F5 & $64^{\circ} 29.99^{\prime} 013^{\circ} 29.99^{\prime}$ & 430 & Mineral fertilization & $3.5 \times 7.5$ & $1.75 \times 3.25$ & 4 & Picea abies \\
\hline
\end{tabular}

rich cambrian-silurian bedrocks. In Nord-Trøndelag county in mid-Norway, two fields were established in 2008 (F3 and F4) and one in 2009 (F5) on silty sand soil in a geology dominated by sandstone, clay shale and granite. The F3 field located in Snåsa municipality was situated on two parallel moraine ridges differing in growth and yield performance. The forest had been clear cut approximately 25 years earlier and newly established small trees, mainly of birch, were cut in June 2008, previous to establishment of F3. In Lierne municipality F4 was situated on a southern slope of uniform growth conditions, where Norwegian spruce (Picea abies L.) trees were clear cut five years earlier. The field was surrounded by Norwegian spruce forest. Because of low fruit yield in F4 due to browsing and weeds, F5 (situated close to F4) was established in 2009. This field was dominated by a uniform E. blueberry population almost without weeds, and had not been browsed. It was harvested in 2009 to estimate yield level in the area that year. In 2010 and 2011 the fruit was eaten by birds.

\subsection{Climatic registrations}

Meteorological stations (HOBO ${ }^{\mathrm{TM}}$, USA) were located at F1 (Bardu), F3 (Snåsa) and F4/F5 (Lierne) (see Table 1 for further description of the fields). Temperature in ${ }^{\circ} \mathrm{C}$, Relative Humidity (RH) in \%, par radiation (PAR) in $\mu \mathrm{mol} \mathrm{m} \mathrm{m}^{-2} \mathrm{~s}^{-1}$ and rainfall in $\mathrm{mm}$ were recorded continuously. Missing temperature and precipitation data were supplemented from nearby meteorological stations Bardufoss in Målselv municipality (F1/F2), Kjøbli in Snåsa municipality (F3) and Nordli in Lierne municipality (F4/F5) [29]. Average temperatures at Kjøbli were reduced $0.7^{\circ} \mathrm{C}$ to fit the $\mathrm{F} 3$ location, which was situated at $100 \mathrm{~m}$ higher altitude.

\subsection{Fertilization experiments}

\subsubsection{Mineral fertilization}

Fertilizer treatments consisted of combinations of ammoniumsulfate $\left(\mathrm{NH}_{4} \mathrm{SO}_{4}\right)$ and YaraMila Opti-Start 12-230 (Yara ${ }^{\mathrm{TM}}$, Norway) at four different levels in 4 plots per block of F3, F4 and F5. The experimental design was a completely randomized block design with five replications in F3 and F4 and four replications in F5 (Table 1). Fertilizer combinations were; 1) control, $0 \mathrm{~kg} \mathrm{NP} \mathrm{per} \mathrm{ha}{ }^{-1}$ (NOP0); 2) $30 \mathrm{~kg} \mathrm{~N}$ and $20 \mathrm{~kg} \mathrm{P}$ (N30P20) per ha ${ }^{-1}$; 3) $30 \mathrm{~kg} \mathrm{~N}$ and $40 \mathrm{~kg} \mathrm{P}(\mathrm{N} 30 \mathrm{P} 40)$ per ha $^{-1}$ and 4$) 60 \mathrm{~kg} \mathrm{~N}$ and $40 \mathrm{~kg} \mathrm{P}$ (N60P40) per ha ${ }^{-1}$. Fertilization was undertaken first week of August in 2008 and in later years first week of June and first week of August.

\subsubsection{Fertilization using compost and wood chips}

The experiments were started at two fields in 2009. Each field was a complete randomized block design with three replications and three treatments [1) 2.5 liter compost per $\left.\mathrm{m}^{2}, 2\right) 2.5$ liter wood chips per $\mathrm{m}^{2}$ and 3) control] (Table 1). Fertilizers were applied once in first week of July 2009. The nutrient levels of wood chips composted with sheep manure have been published earlier [43]; $\mathrm{pH} 9.2,36 \%$ dry matter, $10 \mathrm{~kg} / \mathrm{t}$ total $\mathrm{N}, 0,3 \mathrm{~kg} / \mathrm{kg} \mathrm{NH} 4-\mathrm{N}$, (no $\left.\mathrm{NO}_{3}-\mathrm{N}\right)$, $1,9 \mathrm{~kg} / \mathrm{t} \mathrm{P}, 14 \mathrm{~kg} / \mathrm{t}$ potassium, $5,2 \mathrm{~kg} / \mathrm{t}$ calcium, $1,3 \mathrm{~kg} / \mathrm{t}$ magnesium. The $\mathrm{C} / \mathrm{N}$ ratio is approximately 15 . 


\subsection{Cutting of tillers and site treatment}

Pruning treatments were undertaken in F3, Snåsa, after fruit harvest in 2008 as 1) control [uncut] and 2) tillers cut close to the ground; all plots in two replicates were cut - one replicate on the south and one replicate on the north ridge, randomly selected within ridges. The site treatments were 1) south ridge (three blocks) and 2) north ridge (two blocks). Both ridges were at the same altitude and oriented east-west separated by 50 meters.

\subsection{Growth measurements}

Growth measurements were undertaken at different dates at the different sites. In the north-Norwegian fields F1 and F2, plant growth were registered June 2010 and August 2011, while at F3 and F4 in mid-Norway measurements were undertaken in early September both in 2010 and 2011. Growth was not registered in F5. The parameters used for measurements differed somewhat between north- and mid-Norway. In F1 and F2 growth was registered on 10 randomly selected tillers from each plot along the diagonal between opposite corners across the plot. The term tiller is used for a branching shoot germinating from a bud on the rhizome [8]. Selected plants of 2010 were marked, to perform measurements on the same plants in 2011. Registered parameters were tiller height (from ground to top of the longest shot in $\mathrm{mm}$ ), number of branches on the tiller and length of 10 annual shots (mm). One plot in F2 had no E. blueberry tillers along the diagonal, while one plot only had 6 tillers. Where plants or markings were missing in 2011, new plants were randomly selected along the same diagonal as previous year, if present. In 14 cases no alternative plants were available and the number of registrations was reduced accordingly.

In mid-Norway growth was registered in F3 and F4 when short shots growing from LS buds, that developed previous year, were fully developed and fruits were ripe (Fig. 1). Registrations were undertaken at both fields in early September of 2010 and 2011. Growth was not measured in F5. Two to five tillers (depending on size of the tiller) were randomly selected from each plot to achieve at least 24 long shoots (LS) developed the previous year, for registrations. The lengths of long shoots were measured $(\mathrm{mm})$, and nodes on each long shoot were counted. Similar registrations were made on short shoots (SS) growing from LS nodes. Berries, which mainly developed from the lowest or second lowest node of a short shoot (SS), were counted and diameters were measured (mm).

\subsection{Estimation of yield}

In F1 and F2 all berries within the experimental plots were picked at maturity in a period between 19th August and 7th September 2010 and between 10th and 15th August 2011. In Mid-Norway fruit yield was recorded all years in late August at F3, and in 2009 in F5; F4 was not harvested because of unreliable data (strong browsing and high population of weavy hairgrass in 2009). In all plots yields were registered in grams per plot. Yields were adjusted according to the proportions of E. blueberry plant cover in each plot.

\subsection{Soil sampling and soil analysis}

Soil sampling in F1 to F4 was undertaken with ten samples randomly distributed within each block, similarly at all replications (Table 1). To get a best possible estimate of nutrient status, the soil was sampled to a depth including both the O, E and B horizons, respectively organic, eluvial and illuvial horizon. Sampling was undertaken by pressing a $30 \mathrm{~cm}$ cylinder bore into the soil. All fields were podzol soils and depths of layers were measured from the core taken out of the bore. Each layer was thereafter separated, dried, sieved $<2 \mathrm{~mm}$ and stored for chemical and physical analysis. In F5 three samples were taken from each block randomly along a corner to corner diagonal. The physical measurements taken were grain size (clay, silt, sand and grain $>2 \mathrm{~mm}$ ) [6] and volume weight of O-layer calculated based on layer volume and dry weight of the samples before sieving. Chemical analyzes were loss on ignition $\{3-5 \mathrm{~g}$ of a soil sample is ignited overnight at $550^{\circ} \mathrm{C}$ and calculated in percent of soil dry matter (dried at $105^{\circ} \mathrm{C}$ over- night) $\}$ [24], total $\mathrm{C}$ and $\mathrm{N}$ in O-layer [32,], $\mathrm{pH}$ in a water to soil ratio (v/v) of 2.5, plant available nutrients measured as ammonium lactate extractable $\mathrm{P}, \mathrm{K}, \mathrm{Mg}$ and $\mathrm{Ca}$ [4], $\mathrm{P}, \mathrm{Fe}$ and $\mathrm{Al}$ solved in oxalic acid [56], in E- and $\mathrm{B}-$ layers. 


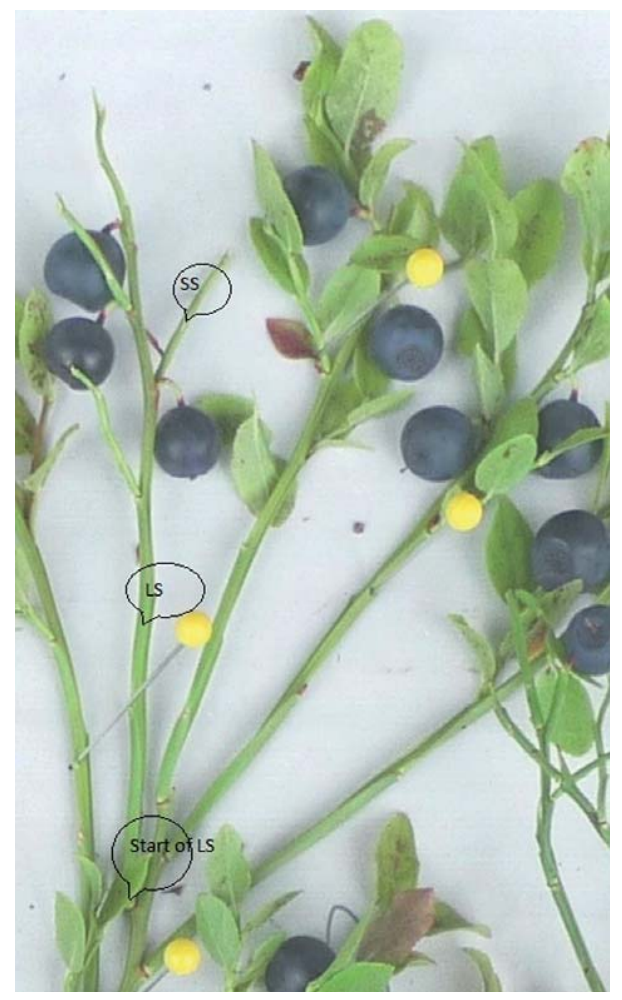

Fig. 1. Part of EB (V. myrtillus L.) tiller with long shoots and short shoots. The long shoot (LS) stripped for leaves grew the previous year from a LS - node developed the year before (start of LS), and hold four SSs from present year. Photo: R. Nestby.

\subsection{Statistics}

The statistical analyses of data from Fields F3-F5 were performed using SAS- GLM, -Tabulate and - Graph procedures [44]. Statistical analysis of fields F1 and F2 were undertaken by the GLM procedure of Minitab 15.

\section{Result and discussion}

\subsection{Soil properties and expected effects of soil}

The soils in the field areas are podzolic moraine with well-developed humus layers, which is nutrient limited soil with low $\mathrm{pH}$ (Table 2). In these acid forest soils the horizontal rhizomes and roots of E. Blueberry were mostly developed in the $\mathrm{O}$ layer, but the $\mathrm{E}$ and $\mathrm{B}$ layers may have contributed significantly to the nutrient supply. Though the content of plant available $\mathrm{P}, \mathrm{K}, \mathrm{Mg}$ and $\mathrm{Ca}$ is generally low in the mineral soil layers, mycorrhiza could enhance the availability of especially phosphorus in these very acid soils. In the O-horizon material the content of macro nutrients are high compared to the mineral soil layers measured on weight basis. The plant roots are growing in a volume of soil and it is more correct to compare the nutrient content on volume basis than on weight basis. On volume basis the $\mathrm{P}$ and $\mathrm{Ca}$ content is low, $\mathrm{K}$ is medium and $\mathrm{Mg}$ is high according the Norwegian classification system for cultivated soils [24]. As shown in Table 3 the content and the quality of the organic material varied between sites. The $\mathrm{N}$ content in the humus $(\% \mathrm{~N})$ in $\mathrm{F} 1$ was significantly higher than at other sites, most likely because of the Betula pubescens vegetation and nutrient rich bottom vegetation compared to the pine and spruce forest sites. Combined with a significant higher amount of P in the O-layer than the F3 and F4 sites in mid-Norway (Table 2), this may have influenced $\mathrm{E}$. Blueberry growth; even though $\mathrm{C} / \mathrm{N}$ ratio for the organic material was in the interval of 27 to 36 between fields, which indicate limited possibility for mineralization of nitrogen as plant nutrient. 
Table 2

Loss on ignition and chemical properties of O-, E- and B-layers of soils at five locations in Norway

\begin{tabular}{|c|c|c|c|c|c|c|c|c|c|c|c|}
\hline ID & Layer & $\begin{array}{c}\text { Loss on ignition } \\
(\%)\end{array}$ & $\mathrm{pH}$ & P-AL & $\mathrm{K}-\mathrm{AL}$ & $\begin{array}{l}\mathrm{Mg}-\mathrm{AL} \\
\mathrm{mg}\end{array}$ & $\begin{array}{r}\mathrm{Ca}-\mathrm{AL} \\
\mathrm{kg}^{-1}\end{array}$ & P-ox & $\mathrm{Fe}-\mathrm{ox}$ & Al-ox & $\begin{array}{r}\operatorname{PSD}^{1} \\
(\%)\end{array}$ \\
\hline \multirow[t]{3}{*}{$\mathrm{F} 1$} & $\mathrm{O}$ & $42.7^{\mathrm{C}}$ & $4.37^{\mathrm{BC}}$ & $129.0^{\mathrm{AB}}$ & $561.0^{\mathrm{A}}$ & $438.0^{\mathrm{A}}$ & $1518.0^{\mathrm{A}}$ & & & & \\
\hline & $\mathrm{E}$ & $3.73^{\mathrm{E}}$ & $4.13^{\mathrm{DE}}$ & $8.9^{\mathrm{E}}$ & $32.4^{\mathrm{D}}$ & $30.0^{\mathrm{C}}$ & $78.7^{\mathrm{C}}$ & $63.0^{\mathrm{C}}$ & $1800.0^{\mathrm{EF}}$ & $639.0^{\mathrm{C}}$ & $7.2^{\mathrm{A}}$ \\
\hline & B & $4.72^{\mathrm{E}}$ & $4.49^{\mathrm{B}}$ & $5.2^{\mathrm{E}}$ & $15.8^{\mathrm{D}}$ & $21.0^{\mathrm{C}}$ & $44.6^{\mathrm{C}}$ & $190.0^{\mathrm{A}}$ & $12690.0^{\mathrm{C}}$ & $2813.0^{\mathrm{B}}$ & $3.7^{\mathrm{C}}$ \\
\hline \multirow[t]{3}{*}{$\mathrm{F} 2$} & $\mathrm{O}$ & $68.0^{\mathrm{A}}$ & $4.10^{\mathrm{DE}}$ & $140.0^{\mathrm{A}}$ & $569.0^{\mathrm{A}}$ & $440.0^{\mathrm{A}}$ & $1482.0^{\mathrm{A}}$ & & & & \\
\hline & $\mathrm{E}$ & $2.67^{\mathrm{E}}$ & $4.11^{\mathrm{DE}}$ & $5.4^{\mathrm{E}}$ & $20.0^{\mathrm{D}}$ & $17.8^{\mathrm{C}}$ & $52.0^{\mathrm{C}}$ & $32.0^{\mathrm{CD}}$ & $692.0^{\mathrm{F}}$ & $617.0^{\mathrm{C}}$ & $5.8^{\mathrm{B}}$ \\
\hline & B & $3.51^{\mathrm{E}}$ & $4.46^{\mathrm{B}}$ & $4.3^{\mathrm{E}}$ & $9.4^{\mathrm{D}}$ & $19.8^{\mathrm{C}}$ & $49.3^{C}$ & $133.0^{\mathrm{B}}$ & $8450.0^{\mathrm{D}}$ & $2367.0^{\mathrm{B}}$ & $3.6^{\mathrm{C}}$ \\
\hline \multirow[t]{3}{*}{ F3 } & $\mathrm{O}$ & $51.7^{\mathrm{BC}}$ & $4.05^{\mathrm{E}}$ & $103.0^{\mathrm{C}}$ & $410.0^{\mathrm{B}}$ & $359.0^{\mathrm{B}}$ & $886.0^{\mathrm{B}}$ & & & & \\
\hline & $\mathrm{E}$ & $2.60^{\mathrm{E}}$ & $4.25^{\mathrm{CD}}$ & $4.6^{\mathrm{E}}$ & $16.2^{\mathrm{D}}$ & $18.6^{\mathrm{C}}$ & $56.3^{\mathrm{C}}$ & $22.0^{\mathrm{D}}$ & $1670.0^{\mathrm{EF}}$ & $469.0^{\mathrm{C}}$ & $3.0^{\mathrm{CD}}$ \\
\hline & B & $9.69^{\mathrm{E}}$ & $4.44^{\mathrm{B}}$ & $6.5^{\mathrm{E}}$ & $22.7^{\mathrm{D}}$ & $24.1^{\mathrm{C}}$ & $89.3^{\mathrm{C}}$ & $129.0^{\mathrm{B}}$ & $23050.0^{\mathrm{B}}$ & $6250.0^{\mathrm{A}}$ & $1.3^{\mathrm{E}}$ \\
\hline \multirow[t]{3}{*}{$\mathrm{F} 4$} & $\mathrm{O}$ & $28.1^{\mathrm{D}}$ & $4.49^{\mathrm{B}}$ & $78.1^{\mathrm{D}}$ & $319.0^{\mathrm{C}}$ & $291.0^{\mathrm{B}}$ & $825.0^{\mathrm{B}}$ & & & & \\
\hline & $\mathrm{E}$ & $3.18^{\mathrm{E}}$ & $4.44^{\mathrm{B}}$ & $7.2^{\mathrm{E}}$ & $18.4^{\mathrm{D}}$ & $25.9^{\mathrm{C}}$ & $80.0^{\mathrm{C}}$ & $52.0^{\mathrm{CD}}$ & $3550.0^{\mathrm{E}}$ & $870.0^{\mathrm{C}}$ & $3.5^{\mathrm{CD}}$ \\
\hline & B & $6.17^{\mathrm{E}}$ & $4.67^{\mathrm{A}}$ & $5.3^{\mathrm{E}}$ & $26.9^{\mathrm{D}}$ & $17.8^{\mathrm{C}}$ & $60.8^{\mathrm{C}}$ & $197.0^{\mathrm{A}}$ & $21190.0^{\mathrm{B}}$ & $5580.0^{\mathrm{A}}$ & $2.2^{\mathrm{DE}}$ \\
\hline \multirow[t]{3}{*}{ F5 } & $\mathrm{O}$ & $57.1^{\mathrm{AB}}$ & $4.13^{\mathrm{DE}}$ & $114.0^{\mathrm{BC}}$ & $445.0^{\mathrm{B}}$ & $465.0^{\mathrm{A}}$ & $1335.0^{\mathrm{A}}$ & & & & \\
\hline & $\mathrm{E}$ & $4.76^{\mathrm{E}}$ & $4.17^{\mathrm{DE}}$ & $9.2^{\mathrm{E}}$ & $28.0^{\mathrm{D}}$ & $32.0^{\mathrm{C}}$ & $79.5^{\mathrm{C}}$ & $48.0^{\mathrm{CD}}$ & $2750.0^{\mathrm{EF}}$ & $641.0^{\mathrm{C}}$ & $4.2^{\mathrm{C}}$ \\
\hline & B & $9.90^{\mathrm{E}}$ & $4.54^{\mathrm{AB}}$ & $8.6^{\mathrm{E}}$ & $28.2^{\mathrm{D}}$ & $39.8^{\mathrm{C}}$ & $119.5^{\mathrm{C}}$ & $131.0^{\mathrm{B}}$ & $25540.0^{\mathrm{A}}$ & $5188.0^{\mathrm{A}}$ & $1.3^{\mathrm{E}}$ \\
\hline
\end{tabular}

${ }^{1}$ PSD is the Phosphorus Saturation Degree [55]. Letters indicate significant differences on 5\% levels tested by SAS GLM Tukey.

Table 3

Values of carbon and nitrogen in the soil O-layer at five locations in Norway. All results are average of bulk samples from all replicates within each location

\begin{tabular}{|c|c|c|c|c|c|}
\hline ID & Total C (\%) & Total N (\%) & $\mathrm{C} / \mathrm{N}$ & $\% \mathrm{C}$ in $\mathrm{OM}$ & $\% \mathrm{~N}$ in $\mathrm{OM}$ \\
\hline F1 & $26.3^{B C}$ & $0.96^{\mathrm{AB}}$ & $27.3^{\mathrm{C}}$ & $61.6^{\mathrm{A}}$ & $2.25^{\mathrm{A}}$ \\
\hline $\mathrm{F} 2$ & $41.1^{\mathrm{A}}$ & $1.14^{\mathrm{A}}$ & $36.1^{\mathrm{A}}$ & $60.5^{\mathrm{A}}$ & $1.67^{\mathrm{B}}$ \\
\hline F3 & $30.6^{\mathrm{AB}}$ & $0.96^{\mathrm{AB}}$ & $31.9^{\mathrm{AB}}$ & $59.2^{\mathrm{A}}$ & $1.86^{\mathrm{B}}$ \\
\hline $\mathrm{F} 4$ & $16.6^{\mathrm{C}}$ & $0.59^{\mathrm{B}}$ & $28.2^{\mathrm{BC}}$ & $58.8^{\mathrm{A}}$ & $2.08^{\mathrm{B}}$ \\
\hline F5 & $32.4^{\mathrm{AB}}$ & $1.13^{\mathrm{AB}}$ & $28.8^{\mathrm{BC}}$ & $56.8^{\mathrm{A}}$ & $1.97^{\mathrm{B}}$ \\
\hline
\end{tabular}

Letters indicate significant differences on $5 \%$ levels tested by SAS GLM Tukey.

Phosphor is known to have positive effect on blueberry growth [39]. For plant growth in general phosphorus is essential for a good root development and for seed and fruit formation. Phosphorus is strongly adsorbed in mineral soil at low pH. The sites F1 and F2 had the highest content of plant available P (Fig. 2) in the O-layer and the lowest content of $\mathrm{Fe}$ and $\mathrm{Al}$ in the B-layer (Table 2), which should indicate relatively better $\mathrm{P}$ availability than the other sites. Soils at F3, F4 and F5 are expected to have the highest P sorption capacity in the B layer (lowest PSD values) and plants may be more exposed to $\mathrm{P}$ deficiency because of higher $\mathrm{P}$ sorption energy.

The soil grain size distribution is quite similar in all sites and the soils are classified as silty sand. The F1, F2 and F4 had slightly higher contents of sand and gravel than F3 and F5, but not significantly. A high sand and gravel content may have negative effect on the growth in dry periods because of less water holding capacity. Figure 3 show that thickness of $\mathrm{O}$ - and E-layers varied between sites, but the internal variation is large and the differences are not significant.

\subsection{Effects of field location and climate}

All fields were situated on small clear cuts or partly cut forest sites (Bardu). Size of clear cuts should therefore not give any prevalence for one or the other field considering growth and fruit yield data. However, in contradiction 

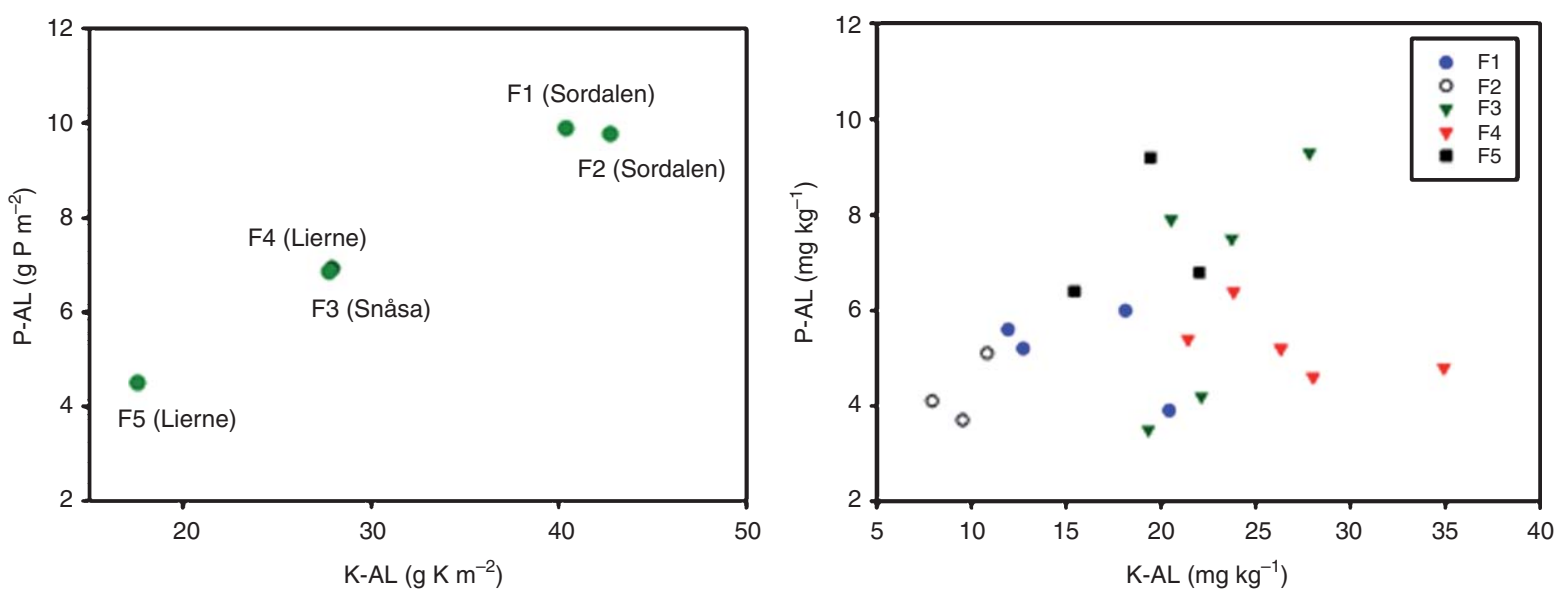

Fig. 2. Ammonium lactate soluble $\mathrm{P}(\mathrm{P}-\mathrm{AL})$ and $\mathrm{K}(\mathrm{K}-\mathrm{AL})$ as total amounts in $\mathrm{g} \mathrm{m}^{-2}$ in the soil O- layer (left) and as concentrations in $\mathrm{mg} \mathrm{kg}^{-1}$ in the B- layer (right).

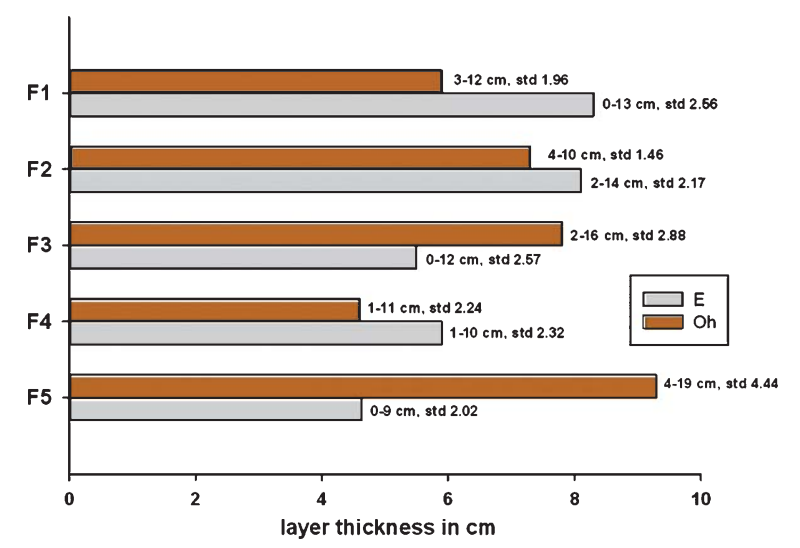

\begin{tabular}{|ccccc|}
\hline ID & $\begin{array}{c}\text { Clay } \\
(\%)\end{array}$ & $\begin{array}{c}\text { Silt } \\
(\%)\end{array}$ & $\begin{array}{c}\text { Sand } \\
(\%)\end{array}$ & $\begin{array}{c}\text { Gravel } \\
>2 \mathrm{~mm}(\%)\end{array}$ \\
\hline F1 & 4 & 35 & 61 & 40 \\
F2 & 3 & 37 & 60 & 47 \\
F3 & 7 & 49 & 44 & 35 \\
F4 & 5 & 36 & 59 & 38 \\
F5 & 6 & 42 & 52 & 29 \\
\hline
\end{tabular}

Fig. 3. Physical soil properties of five forest fields in Norway. Thickness of O-layer as average on all locations with variation given by minimum and maximum values and standard deviation (left), and amounts of clay, silt and sand amounts in percent of the fraction $<2 \mathrm{~mm}$ of $\mathrm{B}$ layers (right); gravel is average amount in E- and B- layers.

to the normally larger clear cuts in Sweden it could be suggested that these relatively small clear cuts demonstrated growth and development benefits for E. blueberry, as shown by others [22, 34].

In Bardu, shot lengths and number of branches were higher in 2011 than 2010, while tiller height was highest in 2010. For length of annual shots and tiller height there were also significant differences between fields. Both mean tiller height (in both years) and shot length in 2010 were larger in F1 than in F2 (Table 4), which could be expected because of higher N-content in the F1- humus. The most profound differences between years were the berry yield of F1, which was very low in 2011 compared to 2010. In 2010 the yields were even between F1 and F2 and the yield in F2 was only slightly below this level in 2011 (Table 10). The weather was warmer and drier in 2011 than 2010 (Table 5) and the dry conditions could explain low berry production in F1 in 2011, however the soil is not lighter in F1 than in F2. Frost damages and browsing might explain why tiller height were lower in 2011 than in 2010, but most likely because some of the tillers measured the first year died back and new and shorter ones were measured next year.

In mid-Norway plants had longer long shoots with more nodes per shoot at F3 (Snåsa) than at F4 (Lierne) in both years, but no difference in number of short shoots bursting from the nodes was observed either year in control 
Table 4

Effect of adding organic matter (OM) in forest fields F1 and F2 in Bardu municipality Norway, on tiller height (T) in mm, number of branches per tiller (B/T) and length of annual short shots (SS) in mm

\begin{tabular}{|c|c|c|c|c|c|c|}
\hline \multirow[t]{3}{*}{$\mathrm{OM}$} & \multicolumn{6}{|c|}{ Growth parameters } \\
\hline & \multicolumn{2}{|c|}{$\mathrm{T}$} & \multicolumn{2}{|c|}{$\mathrm{B} / \mathrm{T}$} & \multicolumn{2}{|c|}{ SS } \\
\hline & $\mathrm{F} 1$ & $\mathrm{~F} 2$ & $\mathrm{~F} 1$ & $\mathrm{~F} 2$ & $\mathrm{~F} 1$ & $\mathrm{~F} 2$ \\
\hline \multicolumn{7}{|l|}{2010} \\
\hline Wood chips & 208.1 & 181.8 & 15.1 & 13.9 & 15.9 & 13.8 \\
\hline Compost & 210.5 & 189.4 & 18.9 & 9.8 & 16.3 & 12.4 \\
\hline Control & 168.7 & 184.7 & 10.2 & 21.2 & 15.0 & 9.2 \\
\hline Mean & 195.8 & 186.0 & 14.7 & 15.2 & 15.9 & 11.8 \\
\hline $\mathrm{Se}$ & $5.70^{* * *}$ & $4.90^{\mathrm{ns}}$ & $1.83^{\mathrm{ns}}$ & $1.43^{* * *}$ & $0.65^{\mathrm{ns}}$ & $0.74^{* * *}$ \\
\hline \multicolumn{7}{|l|}{2011} \\
\hline Wood chips & 202.7 & 155.2 & 23.8 & 20.9 & 28.3 & 31.0 \\
\hline Compost & 195.5 & 187.7 & 23.8 & 14.2 & 29.2 & 26.6 \\
\hline Control & 169.9 & 171.1 & 14.6 & 17.1 & 32.4 & 29.9 \\
\hline Mean & 188.8 & 174.9 & 20.6 & 16.6 & 32.3 & 32.7 \\
\hline $\mathrm{Se}$ & $5.76^{*}$ & $5.27^{\mathrm{ns}}$ & $2.09^{\mathrm{ns}}$ & $1.54^{\mathrm{ns}}$ & $1.98^{\mathrm{ns}}$ & $3.06^{\mathrm{ns}}$ \\
\hline
\end{tabular}

$\mathrm{Ns},{ }^{*},{ }^{* *},{ }^{* * *}$ are respectively no significance and significance on $5 \%, 1 \%$ and $0.1 \%$ levels.

Table 5

Mean temperature in ${ }^{\circ} \mathrm{C}$ and mm precipitation in the growing seasons 2009-2011 of four forest fields (FF) in Norway. F5 is similar to F4

\begin{tabular}{|c|c|c|c|c|c|c|}
\hline \multirow[t]{2}{*}{$\mathrm{FF}$} & \multirow[t]{2}{*}{ Year } & \multicolumn{5}{|c|}{ Monthly temperature } \\
\hline & & May & June & July & Aug & Sept \\
\hline $\mathrm{F} 1 / \mathrm{F} 2$ & 2009 & 8.4 & 9.9 & 14.1 & 14.2 & 8.1 \\
\hline F3 & & 7.9 & 10.4 & 14.2 & 13.6 & 8.6 \\
\hline $\mathrm{F} 4$ & & 6.8 & 10.1 & 13.6 & 13.2 & 8.1 \\
\hline $\mathrm{F} 1 / \mathrm{F} 2$ & 2010 & 6.4 & 8.3 & 13.2 & 10.5 & 6.6 \\
\hline $\mathrm{F} 3$ & & 5.2 & 8.7 & 14.0 & 12.6 & 7.6 \\
\hline $\mathrm{F} 4$ & & 4.8 & 8.5 & 13.6 & 12.2 & 7.5 \\
\hline $\mathrm{F} 1 / \mathrm{F} 2$ & 2011 & 6.5 & 12.8 & 13.2 & 12.9 & 10.3 \\
\hline F3 & & 7.6 & 13.1 & 14.3 & 13.0 & 10.0 \\
\hline \multirow[t]{3}{*}{$\mathrm{F} 4$} & & 6.5 & 12.8 & 14.9 & 12.7 & 9.2 \\
\hline & & \multicolumn{5}{|c|}{ Monthly percipitation } \\
\hline & & May & June & July & Aug & Sept \\
\hline $\mathrm{F} 1 / \mathrm{F} 2$ & 2009 & 55.2 & 37.8 & 31.1 & 87.1 & 126.9 \\
\hline F3 & & 66.1 & 79.2 & 92.9 & 63.8 & 227.2 \\
\hline F4 & & 47.5 & 52.0 & 114.3 & 57.0 & 163.4 \\
\hline $\mathrm{F} 1 / \mathrm{F} 2$ & 2010 & 30.6 & 85.6 & 87.6 & 49.4 & 50.2 \\
\hline F3 & & 84.7 & 110.7 & 117.9 & 37.9 & 56.8 \\
\hline $\mathrm{F} 4$ & & 79.0 & 75.3 & 183.1 & 38.7 & 45.1 \\
\hline $\mathrm{F} 1 / \mathrm{F} 2$ & 2011 & 23.2 & 35.0 & 51.8 & 45.2 & 39.3 \\
\hline F3 & & 61.0 & 104.9 & 73.6 & 139.9 & 168.8 \\
\hline F4 & & 61.5 & 79.2 & 69.3 & 195.6 & 143.6 \\
\hline
\end{tabular}


Table 6

Effect of year on average total yield in $\mathrm{kg} \mathrm{ha}^{-1}$ and fruit disease injury in European blueberry (V. myrtillus L.) at F3 in Norway

\begin{tabular}{llc}
\hline Year & Yield & Disease $\%$ \\
\hline 2008 & 250.6 & 0 \\
2009 & 404.6 & 0 \\
2010 & 193.0 & 6.2 \\
2011 & 122.8 & 3.2 \\
Mean & 240.1 & 2.4 \\
Se & $26.3^{* *}$ & $1.1^{* *}$ \\
\hline
\end{tabular}

$\mathrm{Ns},{ }^{*}, * *, * * *$ indicate respectively no significance and significance on $5 \%, 1 \%$ and $0.1 \%$ levels.

treatment (NOP0) (Table 7). However, short shoot lengths were longer at F4 than at F3 in 2011 and therefore number of nodes per SS was higher (Table 8). The nodes of SS is the site of flower initiation, consequently more fruits were expected in F4 than in F3. On the contrary berry yield was higher in F3 than in F4 both years. The yield differences between years in F3 could be explained by bird feeding (Starling Sturnus vulgaris and Field fare Turdus pilaris). Another reason could be caused by alternate bearing resulting in a strong yield reduction after the high yield in 2009 $[21,22]$. It is also shown that after a high yielding year, plants were more suited to browsing because of changes in chemical composition of shoots and leaves, and browsing would have effect on yield [14, 28, 45].

In 2010 there was one fruit per five short shoots at F3, while fruits were absent in F4 (Table 8). In 2011 the difference between the two fields in fruit number on examined tillers was smaller. Our data do not explain the reason of the difference between the fields in 2010 . However, the results of 2011 could be explained by the relatively short LS growth of F4 caused by spring browsing [14,33]. Short LS-growth gave fewer nodes and thereby fewer Nodes/LS at F4 than at F3. As a consequence of browsing it was observed that SSs sprouted from nodes at a lower position on the LS in F4 than normal. Fruit numbers in the season following spring browsing were negatively affected and growth of short shoots positively affected, similar to growth and yield reactions found in apple after pruning [5].

Climatic factors could also explain some of the yield and growth differences between years in mid-Norwegian fields F3, F4 and F5. Growth conditions in F3 (Snåsa) was slightly warmer and wetter than at (F4) Lierne, in all years (Table 5). This interaction between year and location, together with a thicker O-layer at F3 than at F4 (Fig. 3), can in addition to browsing explain better growth of long shoots at F3 than at F4. Minimum temperatures did not drop below $0^{\circ} \mathrm{C}$ during flowering in any of the three years indicating that frost during flowering could not explain yield difference. Flowering started approximately 1 June at F3 and approximately a week later at F4 and F5. The summers of 2010 and 2011 were rainy (Table 5) which resulted in relatively high percentage of decayed fruits. It is reasonable to expect that this condition also caused some fruit drop and that this could partly explain the low fruit yield these years (Table 6).

\subsection{Effect of fertilization}

\subsubsection{Growth}

In the Bardu field F1 both treatments increased growth of tiller compared with control in both years, but there was no difference between wood chips and compost; for F2 there was no differences. For branching and growth of annual short shoots (SS) at F2 there was an interaction between treatment and year. Untreated plots had more branches and shorter SS than plots treated by compost or wood chips in 2010, while no differences were observed in 2011. For field F1 there was no effect of treatment on neither branching nor SS.

The fields were fertilized using compost and wood chips, materials with high $\mathrm{C} / \mathrm{N}$ ratio and low expected $\mathrm{N}$ mineralization rate, and added to soil that also have a relatively high $\mathrm{C} / \mathrm{N}$ ratio (Table 3 ), they would have no positive short time N-effect on plant growth, but rather negative effect. Any effects of this fertilization would likely be long term, since nutrients would be gradually available during decomposition of wood chips.

Mineral fertilization at Snåsa (F3) and Lierne (F4) municipalities had generally positive effect on elongation of long shoots (LS). However, at F4 in 2011 there was no effect of fertilization. This discrepancy could be explained by browsing of F4 the spring 2011. The relatively strong growth following the two highest fertilization levels at F3 
Table 7

Effect of NP-fertilization in $\mathrm{kg} \mathrm{ha}^{-1}$ in two years on growth of long shoots (LS), number of nodes per LS (Nodes/LS) and number of short shoots per long shoot (SS/LS) in EB (V. myrtillus L.) in two mid-Norwegian forest fields

\begin{tabular}{|c|c|c|c|c|c|c|}
\hline \multirow{4}{*}{$\begin{array}{l}\text { Fertilization } \\
\text { N-P }\end{array}$} & \multicolumn{6}{|c|}{ Growth parameters } \\
\hline & \multicolumn{2}{|c|}{ LS mm } & \multicolumn{2}{|c|}{ Nodes/LS } & \multicolumn{2}{|c|}{ SS/LS } \\
\hline & \multicolumn{6}{|c|}{ Location } \\
\hline & F3 & $\mathrm{F} 4$ & F3 & $\mathrm{F} 4$ & $\mathrm{~F} 3$ & F4 \\
\hline \multicolumn{7}{|l|}{2010} \\
\hline $0-0$ & 42.7 & 25.6 & 6.2 & 4.2 & 2.3 & 2.1 \\
\hline $30-20$ & 34.7 & 33.2 & 5.0 & 4.9 & 1.9 & 2.3 \\
\hline $30-40$ & 35.8 & 27.3 & 5.7 & 4.3 & 2.3 & 2.0 \\
\hline $60-40$ & 43.3 & 36.9 & 6.0 & 5.1 & 1.6 & 2.1 \\
\hline Mean & 39.0 & 30.6 & 5.7 & 4.6 & 2.0 & 2.1 \\
\hline $\mathrm{Se}$ & $7.1^{* *}$ & $6.4^{* * *}$ & $0.6^{* * *}$ & $0.6^{* *}$ & $0.4^{* * *}$ & $0.4^{\mathrm{ns}}$ \\
\hline \multicolumn{7}{|l|}{2011} \\
\hline $0-0$ & 32.7 & 24.7 & 5.5 & 3.5 & 1.9 & 1.8 \\
\hline $30-20$ & 43.9 & 30.0 & 5.9 & 4.1 & 2.6 & 2.3 \\
\hline $30-40$ & 57.8 & 30.2 & 6.3 & 4.3 & 2.8 & 2.2 \\
\hline $60-40$ & 55.5 & 27.8 & 6.3 & 4.1 & 2.7 & 1.9 \\
\hline Mean & 45.8 & 28.0 & 5.9 & 4.0 & 2.4 & 2.0 \\
\hline $\mathrm{Se}$ & $7.7^{* * *}$ & $6.1^{\mathrm{ns}}$ & $0.6^{* *}$ & $0.6^{\mathrm{ns}}$ & $0.4^{* * *}$ & $0.4^{*}$ \\
\hline
\end{tabular}

Ns, ${ }^{*}, * *, * * *$ indicate respectively no significance and significance on $5 \%, 1 \%$ and $0.1 \%$ levels.

Table 8

Effect of location and N-P fertilization in $\mathrm{kg} \mathrm{ha}^{-1}$ on short shoot length in mm (SSl), nodes per short shoot (Nodes/SS) and fruit number per short shoot (Fruits/SS) in EB (V. myrtillus L.) in mid-Norway

\begin{tabular}{|c|c|c|c|c|c|c|}
\hline \multirow{3}{*}{$\begin{array}{l}\text { Fertilization } \\
\text { N-P }\end{array}$} & \multicolumn{6}{|c|}{ Location } \\
\hline & F3 & $\mathrm{F} 4$ & F3 & F4 & $\mathrm{F} 3$ & $\mathrm{~F} 4$ \\
\hline & \multicolumn{2}{|c|}{ SS1 } & \multicolumn{2}{|c|}{ Nodes/SS } & \multicolumn{2}{|c|}{ Fruits/SS } \\
\hline \multicolumn{7}{|l|}{2010} \\
\hline $0-0$ & 26.4 & 29.8 & 5.2 & 5.2 & 0.28 & 0 \\
\hline $30-20$ & 36.1 & 30.1 & 5.6 & 5.0 & 0.21 & 0 \\
\hline $30-40$ & 32.3 & 38.1 & 5.3 & 5.7 & 0.17 & 0 \\
\hline $60-40$ & 39.6 & 33.6 & 5.7 & 5.2 & 0.15 & 0 \\
\hline Mean & 33.3 & 32.9 & 5.4 & 5.2 & 0.20 & 0 \\
\hline $\mathrm{Se}$ & $2.6^{* * * *}$ & $2.9^{* *}$ & $0.2^{* * *}$ & $0.2^{* *}$ & $0.04^{* *}$ & $0^{\mathrm{ns}}$ \\
\hline \multicolumn{7}{|l|}{2011} \\
\hline $0-0$ & 26.4 & 67.3 & 5.0 & 7.4 & 0.26 & 0.09 \\
\hline $30-20$ & 36.0 & 61.4 & 5.6 & 7.1 & 0.30 & 0.12 \\
\hline $30-40$ & 52.1 & 51.4 & 6.7 & 6.8 & 0.18 & 0.12 \\
\hline $60-40$ & 55.1 & 58.0 & 6.8 & 6.7 & 0.07 & 0.08 \\
\hline Mean & 42.2 & 59.4 & 6.0 & 7.0 & 0.20 & 0.10 \\
\hline $\mathrm{Se}$ & $3.5^{* * *}$ & $4.7^{* *}$ & $0.2^{* * *}$ & $0.3^{*}$ & $0.05^{* * *}$ & $0.04^{\mathrm{ns}}$ \\
\hline
\end{tabular}

$\mathrm{Ns},{ }^{*},{ }^{* *},{ }^{* * *}$ indicate respectively no significance, significance on $5 \%, 1 \%$ and $0.1 \%$ level. 
in 2011 compared to 2010 could be explained by long term effect of fertilization (Table 7). At both locations and across years Nodes/LS had similar development as LS, indicating that longer internodes were the reason of increased LS length, and there was interaction between fertilization and location. This increase in Nodes/LS at F3 was not reflected by increased SS/LS ratio at F3 in 2010, rather a decrease at the highest fertilization level. However, in 2011 fertilization increased the SS/LS ratio for all fertilization levels at F3 and at the two medium levels at F4. It could be suggested that it was increased by influence of $\mathrm{N}$-fertilization at intermediate level (N30), since there was no consistent difference between the two intermediate P-levels (Table 7). There was significant interaction between location and fertilization for LS-growth $(\mathrm{P}=0.001)$, and SS/LS $(\mathrm{P}=0.05)$ calculated on the average of two years.

Development of short shoots (SS) were also influenced by fertilization and location, and had a similar pattern as for LS, except for F4 in 2011 (Table 8). That year short shoots grew a lot more at F4 than at F3 and much more than previous year. This discrepancy was due to browsing in early spring by mice and larger animals (moose), eliminating the apical dominance of the LS top bud developed previous year, parallel to pruning of apple trees [5]. The proportional Nodes/SS, behaved similar to SS growth. However, higher value of Nodes/SS caused by increased fertilization was parallel to reduced quotient Fruits/SS. The quotient Fruits/SS was reduced by fertilization both years at F3. At F4 there were no fruits in 2010 and the fruit number was also relatively low in 2011 and not effected by fertilization. It is known from tree fruits that increased fertilization initiates more growth and retards initiation of flower buds, and it could be suggested that the reactions of E. blueberry for growing short shoots are similar [54].

Others have shown that effects of fertilizer on E. blueberry development in natural forests depend on soil nutritional status, water availability, growth temperature etc; and mycorrhiza will interact with fertilization [19, 33, 48]. Such conditions could have confounded the results of our experiments. Earlier studies of E. blueberry plants showed that biomass increased as a response of high $\mathrm{N}$ during two consecutive years, both below and above ground, and was mediated through a change in the number of buds, initially present, which produced shoots with no alteration of number of leaves [13]. This support our results.

\subsubsection{Fruit yield}

For fruit yield in Bardu the mean production over two years was higher in untreated plots $(408.8 \mathrm{~kg} / \mathrm{ha}$; not tabulated) than in plots treated by compost $(201.3 \mathrm{~kg} / \mathrm{ha})$, but not significantly higher than plots treated with wood chips $(263.3 \mathrm{~kg} / \mathrm{ha})$, indicating a negative short term effect of adding organic matter. However, there was interaction between treatment and year and treatment and field (Table 10). In F2 treatment show no significant effect either year, while treatment at F1 show effects both years. In 2010 F1-control yielded more than compost, while in 2011 the situation was opposite. However, even if the difference in 2011 was statistically significant, the actual difference for $2011 \mathrm{in} \mathrm{kg/ha}$ was not very high $(21.9 \mathrm{~kg})$ and thus the results from 2010 had more influence on the total results. The Bardu fields were mulched using organic matter $(\mathrm{OM})$ with high $\mathrm{C} / \mathrm{N}$ ratio and low expected $\mathrm{N}$ - mineralization (Table 3). The feed would have limited short time N-effect on plant growth. Adding OM increased plant growth in the F1 field but not in the F2 field (Table 4). The Betula pubescenc field F1 had lower soil C/N ratio than the Pinus silvestris field F2, and therefore nutrients could have been released at slower rate in F2 than F1 (Table 3).

In mid-Norway yield effects due to fertilization, were recorded only at F3 since F4 had almost no yield because of poor plant establishment following rough clear cutting, abundance of Wavy hairgrass (Deschampsia flexuosa) in 2009 and strong browsing spring 2011. Introduction of NP-fertilization mainly reduced yield at strongest level (Table 9), and N30-P40 yielded equally to control as average of three years. However, that treatment also showed the relatively strongest drop in yield from 2009 to 2011 . The reduction of yield following strongest fertilization level is in agreement with fruit-tree trials showing reduced flower initiation after strong fertilization [16]. At Lierne the F5 field was established to get an idea of the yield potential in the area since F4 was not useful for yield recordings. However, the field showed no effect on yield by fertilization, but nicely demonstrated the strong yield variation within a relatively small area (Fig. 5). The yield-span between block 2 and 3 was approximately $800 \mathrm{~kg} \mathrm{ha}^{-1}$, and the yield potential are higher than shown by others [33, 41].

These results suggest that accumulation of nutrients reduced yield of E. blueberry. However, it is not clear from these experiments if the negative effect is caused by $\mathrm{N}$ or $\mathrm{P}$, or a combination of both. However, most of the roots are in the organic O-layer and it is likely that the fertilizer effect is most pronounced here. Ammonium ions will accumulate in the O-layer because of adsorption to organic functional groups while phosphorus as negative charged phosphate ions, will be leached to the $\mathrm{E}$ and $\mathrm{B}$ layers and adsorbed to $\mathrm{Fe}$ and $\mathrm{Al}$. The leaching is strongly influenced 
Table 9

Effect of NP fertilization on yield in $\mathrm{kg} \mathrm{ha}^{-1}$ of European blueberry (V. myrtillus L.) at F3 in Norway, in three years

\begin{tabular}{lcccc}
\hline Fertilizer & \multicolumn{3}{c}{ Year } \\
\cline { 2 - 5 } N-P & 2009 & 2010 & 2011 & 206.9 \\
\hline $0-0$ & 456.7 & 293.8 & 141.4 & 298.0 \\
$30-20$ & 299.3 & 213.4 & 16.5 & 205.5 \\
$30-40$ & 615.8 & 96.0 & 63.4 & 12.8 \\
$60-40$ & 246.7 & 193.0 & 237.6 \\
Mean & 404.6 & $79.0^{\text {ns }}$ & $38.6^{*}$ \\
Se & $125.9^{\text {ns }}$ & & 239.8 \\
\hline
\end{tabular}

$\mathrm{Ns},{ }^{*},{ }^{* *},{ }^{* * *}$ indicate respectively no significance and significance on $5 \%, 1 \%$ and $0.1 \%$ levels.

Table 10

Effect of mulching with organic matter (OM) on yield in $\mathrm{kg} \mathrm{ha}^{-1}$ of European blueberry (V. myrtillus L.) at F1 and F2 in Bardu in Norway, 2010 and 2011

\begin{tabular}{|c|c|c|c|c|}
\hline \multirow[t]{2}{*}{ OM } & \multicolumn{2}{|c|}{2010} & \multicolumn{2}{|c|}{2011} \\
\hline & F1 & $\mathrm{F} 2$ & $\mathrm{~F} 1$ & $\mathrm{~F} 2$ \\
\hline Wood chips & 431.5 & 395.6 & 16.2 & 209.8 \\
\hline Compost & 183.5 & 304.7 & 29.9 & 287.1 \\
\hline Control & 620.4 & 475.8 & 8.0 & 531.1 \\
\hline Mean & 411.8 & 392.0 & 18.1 & 342.7 \\
\hline $\mathrm{Se}$ & $78.5^{*}$ & $50.2^{\mathrm{ns}}$ & $3.86^{*}$ & $65.3^{\mathrm{ns}}$ \\
\hline
\end{tabular}

$\mathrm{Ns},{ }^{*}, * *, * * *$ indicate respectively no significance and significance on $5 \%, 1 \%$ and $0.1 \%$ levels.

by precipitation. Over time the availability of leached $\mathrm{P}$ will be less available for plant uptake. Because of this soil chemical binding processes it is likely that the negative effect of strongest fertilization level is a result of overfertilization connected mainly to nitrogen accumulation in the O-layer. It should be noted that in 2011 flowers were counted in a small plot at the south ridge. The same plot was harvested in September showing that half of the flowers had not developed into ripe fruits (not tabulated).

\subsection{Effect of tiller cutting on fruit yield}

Cutting of tillers strongly reduced the fruit yield in F3 at Snåsa (Fig. 4). Before cutting in 2008 the fruit yield was not significantly different between the experimental plots. When plants were cut in late autumn 2008 they yielded no fruit in 2009, while controls yielded more than $400 \mathrm{~kg} \mathrm{ha}^{-1}$. Two years after cutting there was some yield on the cut plots, but less than on uncut plots. In the third year after cutting there was no significant difference between cut- and control plots. This shows that E. blueberry need one more year after cutting to produce a normal harvest, compared with the American low bush blueberry (V. angustifolium Ait.) [34, 49], and that cutting every second year is not recommended unless necessary to renew tillers in old fields or to reduce branching of tillers to make mechanical harvest easier.

\subsection{Effect on fruit yield of site at the Snåsa field}

There was no interaction between F3 moraine ridge and fertilization or moraine ridge and year for neither yield nor disease. However, there was a strong main effect of ridge and the north ridge yielded $28.7 \%$ of the south ridge. The distance between ridges was not an argument for the differences, and there were only small differences in thickness of O- and E-layers and in soil particle fractions (not tabulated). However, the amount of $\mathrm{P}, \mathrm{K}$ and $\mathrm{Ca}$ were much lower 

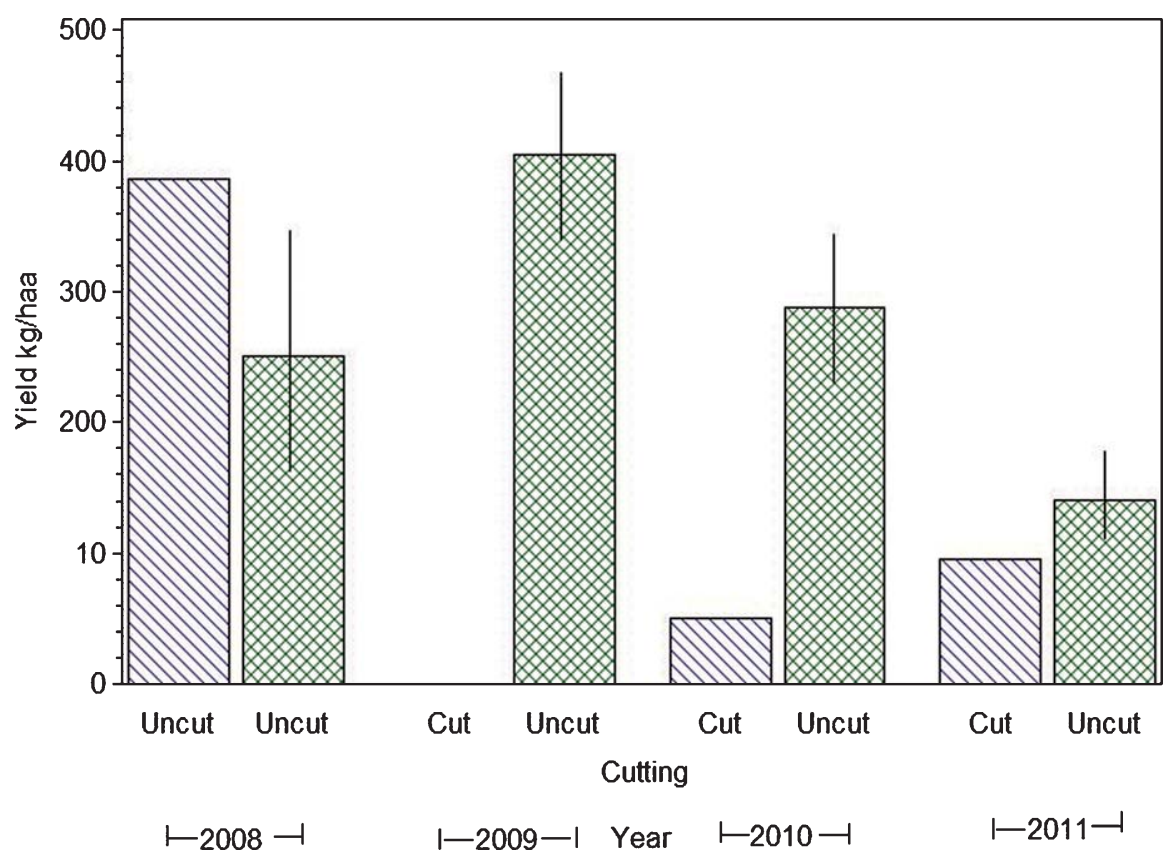

Fig. 4. Fruit yield of European blueberry (V. myrtillus L.) in four years, before (2008) and after cutting tillers close to the ground in October 2008 at Snåsa (F3) Norway. The bars represent Standard Errors of each year.

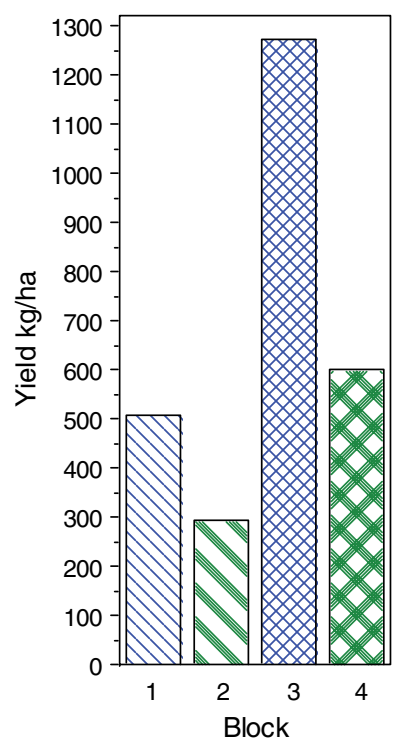

Fig. 5. Fruit yield in 2009 of European Blueberry (V. myrtillus L.) in four blocks at F5 in Norway.

at the north ridge (Table 12), and amount of $\mathrm{N}$ in O-layer was $1.10 \%$ in the south ridge and 0.74 in the north ridge (not tabulated). It could be suggested that the large differences in nutrients were the main reason for the differences in fruit yield. It is surprising though, that fertilization did not increase yield on the north ridge. 
Table 11

Effect of moraine ridges (MR) on yield in kg per hectare and fruit disease injury of European blueberry (V. myrtillus L.) at F3 Norway, as an average of four years

\begin{tabular}{lcc}
\hline MR & Yield & Disease $\%$ \\
\hline South & 346.2 & 2.8 \\
North & 99.4 & 6.2 \\
Mean & 222.8 & 4.5 \\
Se & $50.7^{* * *}$ & $1.7^{*}$ \\
\hline
\end{tabular}

$\mathrm{Ns},{ }^{*},{ }^{* *},{ }^{* * *}$ indicate respectively no significance and significance on $5 \%, 1 \%$ and $0.1 \%$ levels.

Table 12

Effect of two F3 moraine ridges (MR) on loss of ignition and chemical properties of O- and B-layers of soil

\begin{tabular}{lccccrrrrr}
\hline MR & Layer & $\begin{array}{c}\text { Loss on ignition } \\
(\%)\end{array}$ & $\mathrm{pH}$ & $\mathrm{P}-\mathrm{AL}$ & $\mathrm{K}-\mathrm{AL}$ & $\begin{array}{c}\mathrm{Mg}-\mathrm{AL} \\
\mathrm{mg}\end{array}$ & & $\begin{array}{c}\mathrm{Ca}-\mathrm{AL} \\
\mathrm{Kg}^{-1}\end{array}$ & $\begin{array}{c}\mathrm{P} \text { as P-AL } \\
\mathrm{g} \mathrm{m}^{-2}\end{array}$ \\
\hline \multirow{2}{*}{ South } & $\mathrm{O}$ & $59.5^{\mathrm{A}}$ & $4.03^{\mathrm{B}}$ & $118.0^{\mathrm{A}}$ & $429.0^{\mathrm{A}}$ & $403.0^{\mathrm{A}}$ & $987.0^{\mathrm{A}}$ & 7.15 \\
& $\mathrm{~B}$ & $11.0^{\mathrm{B}}$ & $4.41^{\mathrm{A}}$ & $8.2^{\mathrm{B}}$ & $24.0^{\mathrm{B}}$ & $26.3^{\mathrm{B}}$ & $107.0^{\mathrm{B}}$ & 25.8 \\
\multirow{2}{*}{ North } & $\mathrm{O}$ & $40.1^{\mathrm{AB}}$ & $4.08^{\mathrm{B}}$ & $80.5^{\mathrm{A}}$ & $381.0^{\mathrm{A}}$ & $293.0^{\mathrm{A}}$ & $733.0^{\mathrm{A}}$ & 6.59 & 31.11 \\
& $\mathrm{~B}$ & $7.75^{\mathrm{B}}$ & $4.50^{\mathrm{A}}$ & $3.9^{\mathrm{B}}$ & $20.7^{\mathrm{B}}$ & $20.7^{\mathrm{B}}$ & $62.5^{\mathrm{B}}$ & \\
\hline
\end{tabular}

Letters indicate significant differences on $5 \%$ levels tested by SAS GLM Tukey.

\section{Conclusion. Potential for partial-cultivation of native E. blueberry stands in Norway}

The main challenge in developing an E. blueberry industry in Norway is the economy, which besides labour costs and product prices will depend on easily accessed fields and good yields. In Finland it is shown, using recently developed yield models that were included in a stand growth simulator, that a joint production of timber and E. blueberry could give economical gain depending on price and discounting rate [30].

All fields in our research grew on podzolic moraine soil and we can conclude that a thick O-layer is important since the fields with thickest O-layers had the strongest populations of E. blueberry. Thick O-layers and low sand and gravel contents indicate better water preserving capacity. We suggest that layers close to $7 \mathrm{~cm}$ or thicker would be optimal. It is interesting to note that the field with highest $\mathrm{N}$ - percentage in the humus layer was situated in a birch forest. However, $\mathrm{N}$ was not easily available in either field because $\mathrm{C} / \mathrm{N}$ ratios limited the possibility for mineralization of nitrogen as plant nutrient. In areas where O-layers were shallow growth conditions of rhizomes could be improved by importing organic matter.

Plants were clearly affected by climate. Annual shoot growth, number of nodes on the long shoot and number of branches increased with increasing temperature in the growth season. However, higher number of nodes did not increase number of short shoots. Cold winters caused freezing injury with top freezing and even killing of whole tillers.

Fertilization, either mineral or OM, indicate a long term effect on growth of long shoots as a result of internode elongation, and on number of short shoots per long shoot.

Experiments on sites with similar natural or synthetic influence showed large fruit yield differences, and this was probably because of low macronutrient levels. This knowledge could be valuable in future field selection and partial cultivation of native E. blueberry. That NP-fertilization did not increase fruit yield on a site with low vigour was surprising and further experiments should be undertaken to examine the relation between soil macro nutrients and fruit yield to find a sustainable solution to improve the growth conditions.

The improved growth after adding fertilizer and OM was not followed by higher yields, rather the contrary. The rainy conditions could be one reason of relatively poor yield; another reason could be effect of alternate bearing. Also, more attractive shoots and leaves because of fertilization and alternate bearing, would increase browsing and thus have negative effect on fruit yield. 
Cutting of tillers had strong negative effect on yield and it took three years to even out the effect, and should not be recommended in E. blueberry. However, it could be an option to make an even plant population at establishment or to renew tillers in old fields to improve conditions for mechanical harvest.

The results demonstrate that there is a potential of relatively high yield in E. blueberry and that $1260 \mathrm{~kg}$ per hectare reached here is high compared with findings of others [33].

\section{References}

[1] T. Albert, O. Raspe, A.L. Jacquemart. Clonal diversity and genetic structure in Vaccinium myrtillus populations from different habitats. Belgian Journal of Botany. 2004;137:155-62.

[2] O. Atlegrim, K. Sjõberg. Response of bilberry (Vaccinium myrtillus) to clear-cutting and single-tree selection harvest in uneven-aged boreal Picea abies forests. Forest Ecology and Management. 1996;86:39-50.

[3] Y.T. Chen, C. Bogner, W. Borken, C.F. Stange, E. Matzner. Minor response of gross N turnover and N leaching to drying, rewetting and irrigation in the topsoil of a Norway spruce forest. European Journal of soil Science. 2011;62:709-17.

[4] H. Egner, H. Riehm, W.R. Domingo. Untersuchungen uber die chemische Bodenanalyse als Grundlage fur den Beurteilung des Narstoffzustandes der Boden. Kungl Lantbrukshogskolans Annaler. 1960;26:199-215. (In German)

[5] D.C. Elfving. Growth and productivity of 'Empire' apple trees following a single heading-back pruning treatment. HortScience. 1990;25:908-10.

[6] P. Elonen. Particle-size analysis of soil. Acta Agr Fenn. 1971;122:1-122.

[7] A.W. Featherstone. Species profile. Blaeberry (Vaccinium myrtillus). Caledonian Wild! (2002). Available online: http://www.treesforlife.org.uk/newsletter/summer02.html

[8] J.G.K. Flower-Ellis. Age structure and dynamics in stands of European blueberry (Vaccinium myrtillus L.). Ph. D. Dissertation. Res Notes 9. Royal College For. Stockholm (1971), 108 pp.

[9] E. Fremstad. Vegetasjonstyper i Norge. NINA Temahefte 12. Trondheim. NO. (1997), 223 pp. (In Norwegian).

[10] R. Gerdol. Growth performance of two deciduous Vaccinium species in relation to nutrient status in a subalpine heath. Flora Jena. 2005;200:168-74.

[11] V.M. Glass, D.C. Percival, J.T.A. Proctor. Tolerance of lowbush blueberries (Vaccinium angustifolium Ait.) to drought stress. I. Soil water and yield component analysis. Canadian Journal of Plant Science. 2005a;85:911-7.

[12] V.M. Glass, D.C. Percival, J.T.A. Proctor. Tolerance of lowbush blueberries (Vaccinium angustifolium Ait.) to drought stress. II. Leaf gass exchange, stem water potential and dry matter partitioning. Canadian Journal of Plant Science. 2005b;85:919-27.

[13] G.A. Grelet, I.J. Alexander, P. Millard, M.F. Proe. Does morphology or the size of the internal nitrogen store determine how Vaccinium spp. respond to spring nitrogen supply? Functional Ecology. 2003;17:690-9.

[14] S.J. Hegland, K. Rydgren, T. Seldal. The response of Vaccinium myrtillus to variations in grazing intensity in a Scandinavian pine forest on the island of Svanøy. Canadian Journal of Botany. 2005;83:1638-44.

[15] P.R. Hicklenton, J.Y.C. Reekie, K. Mackenzie, D. Ryan. Freeze damage and frost tolerance tresholds for flowers of the lowbush blueberry (Vaccinium angustifolium Ait.). Acta Horticulturae. 2002;574:193-201.

[16] Y. Hikasy, H. Muramatsu, T. Minegishi. Effects of nitrogen application rate on growth, yield and fruit quality of dwarf apple trees. Bull Hokkaido Prefectural Agric Exp, Stations. 1986;55:23-31.

[17] M. Ihalainen, J. Ahlo, O. Kolehmainen, T. Pukkula. Expert models for bilberry and cowberry yields in Finish forests. Forest Ecology and Management. 2002;157:15-22.

[18] M. Ihalainen, T. Pukkula, O. Saastamoinen. Regional expert models for bilberry and cowberry yields in Finland. Boreal Environment Research. 2005; 10:145-58.

[19] E.A. Jeliazkova, D.C. Percival. N and P fertilizers, some growth variables, and mycorrhizae in wild blueberry (Vaccinium angustifolium Ait.). Acta Horticulturae. 2003a;626:97-304.

[20] M. Kalinowski. Influence of pine stand age on chosen features of resources of Vaccinium myrtillus. Lesne Prace Badawcze. 2004;87-91.

[21] L. Kardell, L. Eriksson. Skogsskötselmetodernas inverkan på blåbär och lingon. Resultat av en tioårig försöksserie. SLU Rapport no. 47 (1990). Swedish University of Agricultural Sciences. Department of Environmental Forestry. (In Swedish).

[22] L. Kardell, L. Eriksson. Bärprodukter och markvegetation. Effekter av kvävegödsling och slutavverkning under en 15-årsperiod, $1977-1991$. SLU Rapport no. 60 (1995). Swedish University of Agricultural Sciences. Department of Environmental Forestry. (In Swedish).

[23] G.B. Kinsman. The history of the lowbush blueberry industry in Nova Scotia 1950-1990. Blueberry Producers' Association of Nova Scotia. $1993 ; 154$ pp.

[24] T. Krogstad. Metoder for jordanalyser. Institutt for jordfag. Rapport. 1992;nr. 6/92:32. (In Norwegian).

[25] A.L. Kutchera, E. Lichtenegger. Wurzelatlas mitteleuropäische Waldbäume und Straucher. Leopold Stocker Verlag, Graz - Stuttgart. 2002;604 pp. 
[26] J. Lafond. Application of paper mill biosolids, wood ash and ground bark on wild lowbush blueberry production. Proceedings of the ninth Nort American blueberry research and extension workers conference. Small Fruits review. 2004;3:3-10.

[27] E.A. Maznaya. Structure and productivity of the above-ground phytomass of Vaccinium myrtillus L, and V. vitis-idaea L. coenopopulations in shrub-lichen pine forests (Kola peninsula). Rastitel’nye Resursy. 2001;37:15-22.

[28] C. Melis, A. Buset, P.A. Aarrestad, O. Hanssen, E.L. Meisingset, R. Andersen, A. Moksnes, E. Roskaft. Impact of red deer (Cervus elaphus) grazing on bilberry (Vaccinium myrtillus) and composition of ground beetle (Coleoptera, Carabidae) assemblage. Biodiversity and Conservation. 2006;15:2049-59.

[29] Meterological Institute Norway. eKlima. Available online: http://sharki.oslo.dnmi.no/portal/page?_pageid=33,6979,33_30898:33_30902\&_ dad=portal\&_schema=PORTAL

[30] J. Miina, J.P. Hotanen, K. Salo. Modelling the abundance and temporal variation in the production of bilberry (Vaccinium myrtillus L.) in Finnish mineral forests. Silva Fennica. 2009;43:577-93.

[31] M.D. Myers, J.R. Leake. Phosphodiesters as mycorrhizal P sources. II. Ericoid mycorrhiza and the utilization of nuclei as a phosphorus and nitrogen source by Vaccinium macrocarpon. New Phytologist. 1996; 132:445-51.

[32] D.W. Nelson, L.E. Sommers. Total carbon, organic carbon, and organic matter. In: D.L. Sparks (ed.). Methods of soil analysis. Part 3. Chemical methods, SSSA Book series: 5, Madison, Wisconsin, USA. 1996;961-1010.

[33] R. Nestby, D. Percival, I. Martinussen, N. Opstad, J. Rohloff. The European blueberry (Vaccinium myrtillus L.) and the potential for cultivation. A review. (C2011 Global Science Books. European Journal of Plant Science and Biotechnology. 2011;5(Special issue 1):5-16.

[34] A. Nielsen, Ø. Totland, M. Ohlson. The effect of forest management operations on population performance of Vaccinium myrtillus on a landscape scale. Basic and applied Ecology. 2007;8:231-41.

[35] A.R. Olson, L.J. Eaton. Spring frost damage to placental tissues in lowbush blueberry flower buds. Canadian Journal of Plant Science. 2001;81:779-81.

[36] E. Ögren. Premature dehardening in Vaccinium myrtillus during a mild winter, a cause for winter dieback. Functional Ecology. 1996;10:724-32.

[37] M. Palvainen, L. Finer, H. Mannerkoski, S. Piirainen, M. Starr. Responses of ground vegetation species to clear-cutting in a boreal forest, aboveground biomass and nutrient contents during the first 7 years. Ecological Research. 2005;20:652-60.

[38] M. Passilta, S. Moisio, L. Jaakola, H. Häggman. Voice of the Nordic Wild Berry Industry. A survey among the companies. ISBN 978-95142-9041-1. Oulu University press, Ouly 2009; 84 pp.

[39] D.C. Percival, J.P. Privé, L.J. Eaton, D. Stevens. Use of windbreaks in lowbush blueberry (Vaccinium angustifolium Ait.) production. Acta Horticulturae. 2002;574:309-16.

[40] D.C. Percival, D.E. Stevens, D.E. Janes. Impact of multiple fertilizer applications on the growth, development and yield of the wild blueberry (Vaccinium angustifolium Ait.). Acta Horticulturae. 2003;626:423-29.

[41] L.V. Puchnina. Crop yield of fruits of Vaccinium myrtillus L. in the Pinega national forest. Rastitel nye Resursy. 1996;32:29-32.

[42] D.J. Read. The role of mycorrhizas in the nutrition of ericaceous plants with special reference to the genus Vaccinium L. Productions spontanees Colloque Colmar 17-20 juin. 1980;191-203.

[43] S. Rivedal, S. Øpstad. Gjødselverknad av kompostert sauetalle tilført attlegg og eng ved økologisk dyrking. Grønn kunnskap. 2005;9(2):497-503. (In Norwegian)

[44] S.A.S. Version 9.2 SAS Institute Inc., Cary, NC, USA (2012).

[45] V. Selås. Bestandsvariasjoner hos hønsefugler. Kalde blåbærår er best. Jakt og fiske. 2012;12:50-5. (In Norwegian).

[46] R.M. Seymour, G. Starr, D.E. Yarborough. Lowbush blueberry (Vaccinium angustifolium) with irrigated and rain.fed conditions. Small Fruits review. 2004;3:45-56.

[47] J.M. Smagula, W. Litten, K. Loennecker. Diammonium phosphate application date affects Vaccinium angustifolium Ait. Nutrient uptake and yield. Small Fruits review. 2004;3:87-94.

[48] M. Starast, K. Karp, K. Zimmer, T. Tasa. The effect of fertilizer on the growth of lowbush blueberry (Vaccinium angustifolium Ait.) in mineral soil. Transactions of the Estonian Agricultural University. Agronomy. 2001;212:155-60.

[49] M. Starast, K. Karp, E. Vool, T. Paa, U. Moor. The influence of cutting back on the growth of lowbush blueberry seedlings. Transactions of the Estonian Agricultural University. Agronomy. 2005;220:111-113.

[50] J. Strengbom, M. Walheim, T. Näsholm, L. Ericson. Regional differences in occurrence of understorey forest species reflects differences in N deposition. Ambio. 2003;32:91-97.

[51] S.A. Svalestad. Bærproduksjon hos blåbær (Vaccinium myrtillus), og begrensende faktorer for denne. Thesis, 'University of Environment and Biotechnology’ Ås Norway. 1983;139 pp. (In Norwegian).

[52] M. Tahkokorpi, K. Taulavuori, K. Laine, E. Taulavuori. After-effects of drought-related winter stress in previous and current stems of Vaccinium myrtillus L. Environmental and Experimental Biology. 2007;61:85-93.

[53] K. Taulavuori, K. Laine, E. Taulavuori, T. Pakonen, E. Saari. Accelerated dehardening in bilberry (Vaccinium myrtillus L.) induced by a small elevation in air temperature. Environmental Pollution. 1997;98:91-5.

[54] University of Manitoba, Horticultural inquiries. Top "ten+ 1" reasons why flowering plants fail to bloom. University of Manitoba, Agricultural and fruit scienses, Department of plant science (2013). Available online: http://www.umanitoba.ca/afs/hort_inquiries/miscellaneous/ top_ten_fail_bloom.html 
[55] S.E.A.T.M. Van der Zee, L.G.J. Fokkink, W.H. Van Riemsdijk. A new technique for assessment of reversibly adsorbed phosphate. Soil Sci Soc Am J. 1987;51:599-604.

[56] L.P. Van Reeuwijk. Procedures for soil analysis. 12-2. Acid oxalate extractable Fe, Al, Si. International Soil Reference and Information Centre, Wageningen, The Netherlands. ISBN 90-6672-052-2 (1995). 